FILOZOFIA

Roč. 74, 2019, č. 5

DOI: https://doi.org/10.31577/filozofia.2019.74.5.2

\title{
OD SOCIÁLNÍCH A ENVIRONMENTÁLNÍCH KONFLIKTŮ K POZITIVNÍMU ALARMISMU
}

\author{
MAREK HRUBEC, Centrum globálních studií, Filosofický ústav Akademie věd ČR, Praha, ČR \\ HRUBEC, M.: From Social and Environmental Conflicts to Positive Alarmism \\ FILOZOFIA, 74, 2019, No 5, pp. $366-377$
}

\begin{abstract}
An article addresses the issue of positive alarmism as the first step to articulate an alarming topic of interconnected social and ecological conflicts. While the social and environmental nocflicts are in practice interlinked, analyses of them are usually separated in theory. The article stresses the interconnections. It reflects the fact that civilizations, and especially modern societies in the West, created both development as well as destruction. In order to formulate a normative solution from a perspective of global critical thinking based on the specific macroregional civilizations, the article articulates a methodological move from the dialectic of enlightenment to intersubjective relations among human beings and the nature to overcome the threats of global capitalism and a potential collapse.
\end{abstract}

Keywords: Positive alarmism - Critical - Environmental - Social - Global Conflicts - Civilization

Sociální a environmentální konflikty bývají v praxi vzájemně propojeny, v rovině teorie se však zpravidla analyzují odděleně. Vysvětlení této separace není snadné, důvody lze nicméně hledat v povaze vzájemných souvislostí. Prvním krokem při řešení sociálních a ekologických konfliktů a rizik by měla být kritická analýza problematických vazeb mezi sociálními procesy a environmentálním kontextem, odrážejících skutečnost, že moderní společnosti přinášejí jak rozvoj, tak destrukci. To ve druhé fázi vyžaduje provedení důkladné deskriptivní i explanační analýzy. Ve třetí fázi je třeba navrhnout možná řešení, založená na identifikaci a rozvinutí pozitivních normativních aspektů reality, zejména pomocí sociálního a environmentálního udržitelného př́stupu.

Filosofická reflexe těchto problémů probíhá samozrejmě v konkrétních společenských kontextech a s nimi spjatých analýzách, včetně Slovenska a Česka ${ }^{1}$. Již v minulosti se tak objevily impulzy pro identifikaci problémů a zlepšení stávajícího stavu, třebaže se vlivem technokratického uvažování obvykle omezily na povrchní souvislosti mezi environmentálními důsledky a jejich příčnami, a nepronikly tak k určujícím hlubším př̌činám sociálních a civilizačních procesů. Můžeme nicméně ocenit alespoň počáteční pokusy o zlepšení situace. Založení Římského klubu v roce 1968 a publikace jeho první

\footnotetext{
${ }^{1}$ Viz např. St’ahel (2018); Suša, St’ahel (2016).
} 
zprávy Meze růstu (1972) podnítily vznik nejrůznějších iniciativ, které si dokázaly získat společenský vliv. Př́kladem z nedávné doby může být konference o udržitelném rozvoji uspořádaná Organizací spojených národů v Riu de Janeiru v roce 2012, která je důkazem toho, že se světové společenství snaží o serióznější př́stup k environmentálním a sociálním rozvojovým cílům. Na konferenci došlo $\mathrm{k}$ přijetí Cílů udržitelného rozvoje v rámci agendy nazvané Přeměna našeho světa: Agenda pro udržitelný rozvoj 2030 (UN 2012). Některé z dohodnutých cílů již členské státy implementovaly. Je proto namístě dílčí naplňování stanovených závazků kriticky analyzovat a zkoumat pokračující sociální a environmentální konflikty i rizika potenciálních kolapsů.

V roce 2015 vedla Rámcová úmluva OSN o změně klimatu představitele 195 státu $\mathrm{k}$ přijetí Pařǐžské dohody. Jejím hlavním cílem je prosazování globálního přístupu ke hrozbě klimatické změny. Mezi cíli figuruje ,udržení nárůstu průměrné globální teploty výrazně pod hranicí $2{ }^{\circ} \mathrm{C}$ oproti hodnotám před průmyslovou revolucí a úsilí o to, aby nárůst teploty nepřekročil hranici $1,5^{\circ} \mathrm{C}$ oproti hodnotám před průmyslovou revolucí" (UN 2015). Předpokladem je, že takové opatření by společnostem umožnilo rozvoj bez dramatických negativních změn.

V roce 2018 však Mezivládní panel pro změnu klimatu (IPCC) ve Zvláštní zprávě o globálním oteplení (SR15) konstatoval, že globální klimatická změna bude mnohem výraznějuší, než se očekávalo. ${ }^{2}$ Mezivládní panel zdůraznil, že by lidstvo mělo jednat dřive než v roce 2030, jinak hrozí dramatické změny, napřiklad zaplavení rozsáhlých pevninských oblastí. I Světový fond na ochranu prírody ve své zprávě varoval, že „ohromující úbytek biodiverzity, který ukázal poslední Index živé přírody ( $60 \%$ pokles za pouhých 40 let), je neradostnou připomínkou a snad i nejvýmluvnějším důkazem tlaku, jejž na planetu vyvíjíme“ (Lambertini 2018). Uvedené údaje svědčí o nutnosti revoluční transformace jednotlivých společností.

Zmíněné zprávy OSN, jakož i další související reporty jsou veřejnými dokumenty založenými na kombinaci vědeckých analýz a kultivovaných alarmistických tezí, kterých je za situace, kdy korporace a veřejná sféra včetně vládních struktur nejsou v posledních dekádách schopny adekvátně jednat, nutně zapotřebí. Je možné si klást otázku, co se skrývá za tímto novým př́stupem, jež se snaží vyhnout globálnímu kolapsu současného stavu po roce 2030. Lze říci, že v pozadí stojí př́stup, který můžeme označit jako pozitivní alarmismus. Varování a praktická doporučení zde vycházejí z implicitních předpokladů

2 „Množství dopadů klimatické změny, kterému se lze vyhnout tím, že bude globální oteplování omezeno ze 2 a více ${ }^{\circ} \mathrm{C}$ na $1,5^{\circ} \mathrm{C}$. Kupř́kladu v roce 2100 by růst hladiny světového oceánu při globálním oteplování v hodnotě $1,5^{\circ} \mathrm{C}$ činil o $10 \mathrm{~cm}$ méně než při hodnotě $2^{\circ} \mathrm{C}$. Severní ledový oceán se při oteplování o $1,5^{\circ} \mathrm{C}$ ocitne v letních měsících bez ledové pokrývky jen jednou za celé století, zatímco při oteplování o $2{ }^{\circ} \mathrm{C}$ nejméně jednou za deset let. Při oteplování $1,5^{\circ} \mathrm{C}$ ubude 70 až 90 procent korálových útesů, zatímco při oteplování $2{ }^{\circ} \mathrm{C}$ prakticky všechny ( $>99$ procent) zaniknou““ (IPCC, 2018). 
o hlubších a dlouhodobějších tendencích sociálního i civilizačního vývoje, které musíme analyzovat, abychom dokázali daný problém a jeho (ne)možné řešení pochopit.

Je důležité, abychom nyní co nejvíce omezili negativní zásahy naší lidské civilizace do životního prostředí, zároveň je ovšem třeba vzít v potaz, že z dlouhodobé perspektivy tisíců až statisíců let by bylo problematické jen udržitelně konzervovat planetu Zemi. Nebude patrně možné a ani žádoucí zabrzdit přirozený cyklický vývoj planety s ledovými dobami a jejich glaciálními cykly (viz graf s fázemi ochlazení a oteplení). V současné éře antropocénu lidstvo chaoticky a negativně mění ekosystém spíše jen jako nezamýšlený důsledek svých jiných činností, než že by záměrně koncipovalo žádoucí symbiózu lidských a prrírodních procesů. Pokud bude lidská civilizace v dlouhodobé perspektivě chtít přežít, bude se muset pravděpodobně adaptovat na daleko nehostinnější podmínky (cyklické i ojedinělé), než jakým čelíme nyní (Bostrom 2011). To bude patrně provázet pokusy a omyly. Není však ted' nutné děsit čtenáře více, než je třeba. Tento kontext je v tomto článku pouze rámcem, který je možné podrobněji probrat v jiném, samostatném článku, a který pozitivnímu alarmismu umožní ještě další př́iležitosti uplatnění.

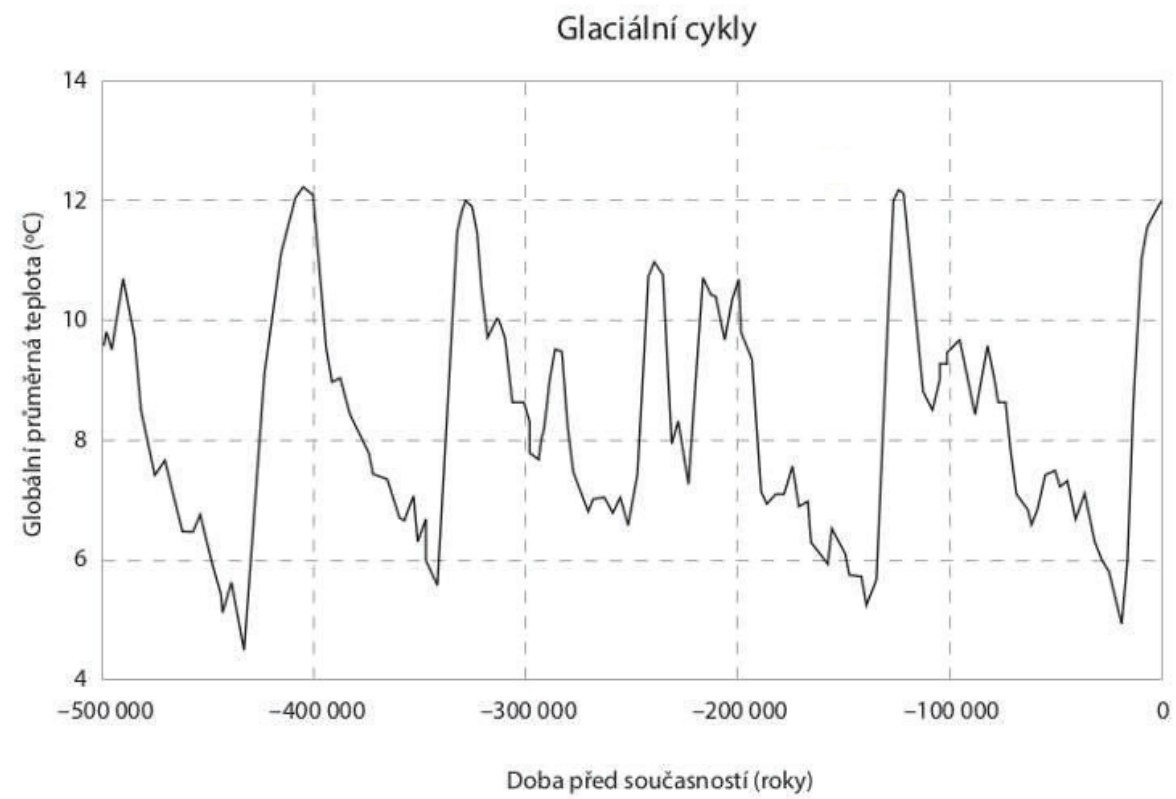

V tomto článku představím otázku sociálních a environmentálních konfliktů a potenciálních řešení v rámci udržitelného př́stupu, a to tak, že nejprve načrtnu hlavní ideje ambivalentní dialektiky dějin západní civilizace i celé lidské civilizace a následně poukážu na nutnost přechodu od monologického $\mathrm{k}$ intersubjektivnímu paradigmatu vztahů mezi lidmi a mezi člověkem a prrírodou. Uvedená změna je podmínkou pro překonání prob- 
lematické dialektiky globálního kapitalismu a civilizace vůbec. Zaměřím se na text, který stál na počátcích tohoto způsobu uvažování a který se zabývá potlačováním přirozenosti a z něho vyplývajících konfliktů. Třebaže práce Theodora Adorna a Maxe Horkheimera o dialektice osvícenství trpí nedostatky, jež lze prísoudit dobovým okol-nostem jejího vzniku, zaslouží si naši pozornost, protože artikuluje dlouhodobé patologické tendence. ${ }^{3}$ Paradoxně je však jimi zároveň poznamenána, jelikož není schopna překročit hranice daného paradigmatu. Její skeptická explanační kritika nicméně může posloužit jako první krok $\mathrm{k}$ artikulaci pozitivního alarmismu ve vztahu k současné zoufalé situaci, aby se následně mohlo přejít $\mathrm{k}$ novějšímu paradigmatu pomocí rozvinutějších a sofistikovaněǰších intersubjektivních globálních analýz z nedávné a současné doby. Má argumentace pritom rozšiřuje a překračuje hranice kritické teorie, a může proto oslovit širší okruh čtenářů.

\section{(1) Dialektika západní civilizace}

Otevření otázky dialektiky civilizace dobře vystihuje metafora Clauda Léviho-Strausse, podle níž už naše civilizace není „křehkou květinkou“, již je třeba na zahrádce chránit před okolními hrozbami (2012 [1955]). Civilizace je vytvářena masovou produkcí, monokulturou. Tento postřeh obrací pozornost $\mathrm{k}$ expanzi civilizace a ztrátě nutnosti ji chránit, protože zesílila natolik, že ochranu zkrátka nepotřebuje, ba naopak. Postoj Léviho-Strausse lze označit za relativně optimistický, jelikož se spokojuje se zachycením nadměrného civilizačního produktivismu a globálního nástupu civilizace. Na tento moment navázali Adorno s Horkheimerem a obohatili jej o explanační kritiku civilizačního procesu.

Masová destrukce, kterou přinesla druhá světová válka, vedla reflexi v Dialektice osvícenství (2007 [1944]) ke stále razantnějšímu odmítání vývoje založeného na ničivé racionalizaci a technologiích, a především ke kritice represe a kulturní manipulace. ${ }^{4}$ Zrod totalitního systému nadvlády považovali za důsledek sociálního vývoje chybného od samotného počátku a za projev rozpínavé racionalizace a s ní spojených technologických patologií, přitomných v dalších fázích rozvoje civilizace. Autoři se zaměřují na převážně negativní aspekty, které tlak civilizace vůči člověku a príŕodě přinášel už v okamžiku jejího vzniku. Jde o odmítnutí civilizace jako takové.

Tento všeprostupující negativismus však vede $\mathrm{k}$ beznaději. Podle mého názoru autoři měli promyslet, jak by bylo možné pokusit se takový patologický rozvoj zvrátit, i kdyby se mělo jednat o pokus marný. Čtenář, který nepřijme perspektivu zvolenou Adornem

\footnotetext{
${ }^{3} \mathrm{~V}$ tomto článku navazuji a využívám své rozbory, které jsem formuloval v: (Hrubec 2011, 125 137); zároveň: Hrubec (2019).

${ }^{4}$ Tento typ kritického myšlení se objevil již v posledním ročníku časopisu Studies in Philosophy and Social Science, který byl původně vydáván ve Frankfurtu Adornovým a Horkheimerovým Institutem pro sociální výzkum (Horkheimer 1941, 365); srov. Horkheimer (1941, 266 - 388); Adorno (1941).
} 
a Horkheimerem, nicméně může ocenit a následovat inspirující koncept sociální kritiky, jejž vypracovali. Jejich analýzu lze číst jako výrazné kritické memento, které leží za naší každodenní zkušeností a naším kritickým př́stupem. Obraz nežádoucích civilizačních tendencí může tvořit pozadí jemnější sociální kritiky. Mohl být doplněn úvahami o potenciálních sociálních a environmentálních transformacích. $\mathrm{K}$ tomu ovšem $\mathrm{v}$ jejich knize nedošlo.

Důsledky technologického rozumu, který měl zvláště od zrodu moderny či osvícenství značný dopad na život člověka, představují výzvu, již nelze přehližžt. Adorno s Horkheimerem se zaměřují na dlouhodobé historické príčiny rozvoje kapitalismu, na obecnou kritiku západní civilizace $\mathrm{s}$ ohledem na určující roli negativních aspektů racionality. Jejich interpretace spatřuje zdroj patologického civilizačního vývoje napříc dějinami v negativních momentech racionálního využívání přirozených procesů, které přispívá ke kontrole přirozenosti a následnému utváření „vztahů společenské nadvlády“.

Jak ve svém Kapitálu poznamenal Karel Marx, ,„[k]apitalistická výroba (...) narušuje metabolickou výměnu mezi člověkem a přírodou, brání návratu jednotlivých prvků spotřebovaných člověkem v podobě potravy a oděvu zpět do země, a tak narušuje podmínky nutné pro udržení úrodnosti půdy. (...) Kapitalistická výroba tedy vyvijí technologie (...) jen za cenu oslabování skutečných zdrojů bohatství - půdy a pracovníka“ (1967 [1867], $505-507)$.

Oba autoři navazují na Marxe a rozšiřují kritiku z perspektivy civilizace. Kritizují př́iliš široké užívání rozumu, jež má kořeny ani ne tak v 18. století, jak se obvykle uvádí, nýbrž už v antice. Jejich široký koncept osvícenství provází celé dějiny Západu. Úsilí o přežití a překonání nástrah prŕrody vedlo od počátku západní civilizace $\mathrm{k}$ instrumentalizaci lidského rozumu, což je verze rozumu, který Horkheimer a Adorno, mají na mysli, když hovoří obecně o rozumu. $\mathrm{V}$ důsledku tohoto př́stupu a propasti mezi prírodou a kulturou se vyvinuly trri druhy kontroly a reifikace prírody. Za prvé, kontrola vnější, okolní prírody, v níž člověk žije. Za druhé, kontrola vniťrní př́rody, tedy instinktů, přirozenosti člověka. A za třetí, kontrola lidí navzájem, související s předchozím typem kontroly.

Když Adorno s Horkheimerem vysvětlují problém instrumentálního rozumu, sahají po kanonických textech západní civilizace, a na příkladu Homérova díla (tedy před více než 2700 lety) ukazují, že rozvoj instrumentality od starověku do současnosti má převážně negativní dopady. V základech vývojové dialektiky západní civilizace leží popření prirozenosti a šírení takového druhu racionality, která je ve skutečnosti iracionalitou. Vnější príroda začala být paradoxně ovládána zároveň s osvobozováním člověka, disciplinovaného a zotročeného. Jsme svědky rozmachu technické racionality a jejího samoúčelného rozvoje, v němž se vytrácí zprostředkující role a z něhož se vytlačuje původní účel, jemuž měla sloužit. Technická racionalita se paradoxně stává brzdou rozvoje člověka a jeho okolí a vede ke krizím. Tato evoluční dialektika se stala dialektikou kapitalismu s dlouhodobými historickými důsledky. Meziválečná hospodářská krize a s ní související 
vzestup fašismu a nacismu představují pouhé vyvrcholení dlouhodobých vývojových tendencí, které od samého počátku lidských dějin činily z prostředků účel.

Homérova Odysseia (1999) odhaluje počátky vývoje patologických a krizových prvků lidského rozumu. Odysseus, rozvíjející instrumentální racionalitu, se snaží o kontrolu okolní prŕrody, vlastní přirozenosti i prrirozenosti svých poddaných. Odysseus vykonává kontrolu, aby zachránil svůj život a posílil svou moc, zároveň však skrze kontrolu oslabuje život. Po válce s Trojany nemůže nalézt cestu domů, putuje a bloudí, zažívá vzestupy i pády a rozvíjí technickou racionalitu jako prostředek přežití a spotřeby. To, čeho se neodváží doma ve společenství svých milovaných, si dovoluje na cestách v situaci, kdy je izolován, a bezohledně uplatňuje svůj vlastní „,atomizovaný zájem“. Odtržení od vlastního společenství mu umožňuje prosazovat diktát v konkurenčním boji s ostatními. Jeho př́stup k životu se později stává exemplárním př́ikladem pro moderní západní ekonomiku s její technickou iracionalitou, znemožňující lidem uspokojování jejich skutečných potřeb. Hospodářské krize, masová manipulace, koncentrační tábory a holokaust jsou důsledky zvrácené technické racionality moderní doby. Určujícím zdrojem veškerých těchto projevů lidské nadvlády je spontánní rozvoj technické racionality od počátků lidské civilizace. Subjekt instrumentálního rozumu je subjektem, který se v dějinách vyvíjel od raba k podnikateli a správci.

Homérova Odyssea se určitou formou značně podobá dalším klasickým dílům západní civilizace, jakými jsou Hegelova Fenomenologie ducha (2018 [1806]) či Marxův Kapitál (1967 [1867]). Při psaní svých prací vycházejí autoři z určitého intelektuálního, kulturně predávaného motivu, a sice $\mathrm{z}$ odyseje. Inspiraci nacházeli $\mathrm{v}$ tehdejších zámořských výpravách do Amerik, Afriky a Asie, které měly ve skutečnosti nová území spíše dobýt než jen objevit. Podle Léviho-Strausse bylo z hlediska vnímání mnoha tehdejších lidí cílem výprav nikoli objevení Nového světa, nýbrž znovunalezení ztraceného biblického ráje. V současné globální ére se putování transformovalo do podoby komerčních turistických zájezdů.

Myšlenka odyseje, oživená ve filosofických, vědeckých i uměleckých textech moderní éry (Kosík 1963), spočívala v putování subjektu světem a v poznání světa, jež si daný subjekt osvojil. Subjektem může být jednotlivec, duch, kolektiv v podobě společenské trǐ́dy apod. Vždy ovšem sám sebe poznává skrze vlastní činnost, přeměnu světa, a tudíž i sebe sama. Subjekt přetváří svět a sám se proměňuje. Goethovy vzdělávací romány o Vilému Meisterovi či Rousseauův spis Emil aneb $O$ výchově jsou jen dalšími variantami Homérovy Odysseje, Hegelovy Fenomenologie ducha či Marxova Kapitálu. Všechna tato díla jsou založena na odyseji. Hegelovo putování ducha představuje způsob, jakým vědomí v dějinách prochází rozmanitými fázemi, aby nakonec poznalo sebe sama a stalo se bytím pro sebe. Tato historická ,zkušenost vědomi“" má svou paralelu v Kapitálu, který je odyseou specifické dějinné praxe. Je to způsob, jímž se konkrétní praxe odpoutává od původního produktu práce, prochází různými vývojovými stupni a nakonec se stává 
praktickým aktem založeným na znalosti a přeměně subjektu i jeho okolí. Korporace, následující racionalitu zisku, však dosud $\mathrm{v}$ západních zemích vytvárejí konzumní spotřebitele tím, že je tlačí na „nekonečnou“ cestu permanentního ekonomického růstu a spotřeby na úkor sociálních a environmentálních zájmů.

\section{(2) Dialektika lidské civilizace}

Ačkoli se Adorno s Horkheimerem snaží o pochopení rozvoje celé lidské civilizace, vycházejí omezeně téměř výhradně z kritiky západní kultury. Sledujeme-li směr jejich uvažování, je třeba si navíc uvědomit, že vývojové vzorce ostatních kultur jsou v něčem podobné, ale v jiných aspektech odlišné 5 . Na jednu stranu byly nezápadní kultury zasaženy západní instrumentální racionalitou výrazněji až během kolonialismu, studené války a současného globálního kapitalismu. Na stranu druhou však platí, že i kdyby nezápadní kultury západními koncepty ovlivněny nebyly, lze pozorovat prvky vyskytující se napříč různými kulturami, které zahrnují represivní expanzi a rozvoj s prvky instrumentální racionality. Západní kultura by proto sice měla zůstat $\mathrm{v}$ centru kritiky, ostatní kultury ale není možné opomíjet. Měli bychom podrobovat seriózní kritice instrumentální rozum, ale nezaměřovat se pouze na počátky západní civilizace, nýbrž také na zrod ostatních civilizací, abychom byli následně schopni zasazovat zkoumané otázky do rámce různorodých modernit. Alternativy k evropské Odysseji představují indické eposy Rámájana a Mahábhárata či blízkovýchodní Epos o Gilgamešovi a Starý zákon, mámeli zmínit alespoň některé z klasických paradigmatických textů.

Všechna tato díla názorně ukazují způsoby hledání a putování, což dokládá jednak historický proces rozvoje, jednak proces stupňování instrumentální kontroly lidí a přrirody. Idea putování ztělesňuje cestu subjektu do světa, a to doslovně i metaforicky. Individuální a kolektivní subjekty se dočkávají uznání a dospívají na základě svých činů, jež mění svět i jednající aktéry samotné, tedy vnější přírodu i jejich vnitřní přirozenost. Proměna světa je zde možná prostřednictvím instrumentální racionality, která s sebou přináší rozmanité formy kontroly nad lidmi a př́rodou. Je třeba ovšem dodat, že předkládaná interpretace je založena na objasnění jednání individuálních aktérů, hrdinů z eposů, přičemž chování individuálního subjektu zde nedokonale reprezentuje kolektivní proces vývoje celých kultur, respektive lidské civilizace.

Budeme-li v analýze pokračovat, zjistíme, že se problém instrumentální racionality vyskytuje od úsvitu lidských dějin, a to nejen v rámci represivních systémů, ale v implicitní podobě často i ve sféře vymezující se vưči takovým systémům. Existuje jak v kapitalismu, tak $\mathrm{v}$ jeho moderních alternativách, jak dokládá zkušenost zemí bývalého socialistického tábora. Co se týče environmentální problematiky, je dostatečně známo, jaké reálný socialismus ve východní Evropě a Sovětském svazu měl dopady na životní prostréedí.

\footnotetext{
${ }^{5}$ Srov. Eisenstadt (2002), Arnason (2009), Benjamin (1973).
} 
Ukazuje se tedy, že díky dlouhodobým vývojovým tendencím instrumentální racionality $\mathrm{v}$ rámci lidské civilizace se problém neomezuje pouze na kapitalismus. Ovšem vzhledem $\mathrm{k}$ tomu, že dnes žijeme v podmínkách globálního kapitalismu, musíme čelit systémovým a strukturálním problémům spojeným právě hlavně s ním.

V současné době vlastníci a manažeři korporací a s nimi spjatí politici záměrně dělají $\mathrm{z}$ většiny občanů západního světa spotřebitele, $\mathrm{z}$ lidí na periférích ekonomického systému výrobce či deklasovanou rezervní armádu nezaměstnaných a marginalizovaných a z př́irody zdroj surovin pro své výrobní linky a odpadní skládky. Tento proces vede nejen ke globálním sociálním patologím a nespravedlnostem, ale rovněž $\mathrm{k}$ ničivým důsledkům v podobě globální klimatické změny.

Protože se v současné globální epoše dostávají různé prvky lidské civilizace do vzájemného kontaktu a její rozvoj se stává vskutku celoplanetárním, hypertrofie patologických aspektů instrumentální racionality může způsobit kolaps lidské civilizace. $Z$ toho důvodu musejí být rizika spojená s globálním technologickým rozvojem vnímána jako silný motiv pro další, slibnější analýzy. Jejich zakotvení v rozborech patologií technologického vývoje by však přitom mělo zůstat varováním.

\section{(3) Pozitivní alarmismus: vstř́c globálním intersubjektivním vztahům mezi lidmi a prírodou}

Martin Jay ve své klasické práci o dějinách kritické teorie (1996 [1973]) označil 30. a 40. léta za nejplodnější období činnosti frankfurtského Institutu pro sociální výzkum. S odstupem času ale vidíme, že kritická teorie té doby (zvláště pak v Dialektice osvícenství) sice byla silná v nastolování teoretické agendy a ve svém kritickém zaměření, neprrišla však prakticky s žádnými pozitivními návrhy řešení. Kromě kritiky nabízela jen částečně rozvinutou explanaci, a normativitu téměř zcela přehlížela. Zkoumámeli z tohoto metodologického hlediska dialektiku osvícenství, v návaznosti na Habermase a Honnetha zjistíme, že obsahuje zjednodušující subjekt-objektové paradigma, které neumožňuje dostatečnou explanaci skutečnosti ani rozvinutou normativitu. Instrumentální rozum jakožto monologický př́stup člověka $\mathrm{k}$ člověku a př́rodě je založen na subjekt-objektových vztazích. Tyto vztahy byly podrobeny kritice, ale zvolený rámec nedovolil deskripci intersubjektivní, především komunikativní a sociální roviny lidského života a jeho vztahu $\mathrm{k}$ př́rodě, ani formulaci normativního návrhu intersubjektivně orientovaného př́sstupu řešení patologií a nespravedlností (Hrubec a kol. 2013).

Nejednalo se o adekvátní deskripci dějinného vývoje s různými odchylkami od takové deskripce $\mathrm{v}$ minulosti a od budoucích možností. Je důležité rozlišovat mezi přehnaně generalizující negací racionality jako takové na jedné straně a nutnou kritikou nadvlády technologického či instrumentálního rozumu na straně druhéb. Kritika os-

\footnotetext{
${ }^{6}$ Viz. Habermas (2015), Honneth (2000).
} 
vícenství je proto jako kritická deskripce a deskriptivní kritika problematická, nebot' nabízí jen neurčitou perspektivu.

O vhodný př́stup nešlo ani z normativního hlediska. Zvolená pozice je totiž jednostranná a neadekvátní, jelikož neposkytuje normativní možnost překonání dosavadního stavu. V dějinném vývoji nezbývá žádný prostor pro alespoň dílčí svobodný akt proti negativním tendencím instrumentální racionality. Takový krajně skeptický, beznadějný, bezmála fatalistický postoj neobsahuje možnost vývojové korekce.

Přitom bychom se o překonání jednostranného (zne)užívání instrumentální racionality měli alespoň pokusit. Instrumentální racionalita může být uplatňována pozitivně, neměla by však být jediným a hlavním principem jednání. $\mathrm{V}$ opačném př́padě se stává problematickým předpokladem, na němž mohou být založeny autoritativní neparticipativní systémy. Zvolená pozice může být redefinována tím, že odmítneme přehnanou skepsi a pasivitu a pokusíme se o smysluplné jednání, které umožní zapojení intersubjektivní dimenze rozumu a jednání. To vyžaduje rozvoj adekvátnějších vzorců vztahů jak mezi lidmi navzájem (Honneth 2011), tak mezi lidmi a prírodou, byt’ stále na pozadí patologického technologického vývoje, který ve 20. století vyústil v civilizační regres v podobě dvou světových válek a který i nadále pro lidstvo a životní prostředí představuje hrozbu, nebot' je spojen se současnými hrozbami v podobách planetární homogenizace, nadnárodními autoritativními tendencemi a potenciálem globálního konfliktu (Hrubec 2016).

Analýza musí zahrnovat systémové a strukturální části i prvky spjaté se subjekty. Pokud bychom se však zaměřili výhradně na obecný subjekt lidstva, marginalizovali bychom specifické skupiny, které za problémy nesou největši díl odpovědnosti, a také ty, které proti stávajícím strukturám bojují. Při hledání pozitivních fragmentů sociálního rozvoje jsme pritom stále znovu konfrontováni s otázkou, zda je nejvhodnější cestou analyzovat pouze vlastnosti Odysseovy. Vracíme se tak $\mathrm{k}$ nedořešenému problému Dialektiky osvícenství. Další interpretace od nás vyžaduje inkluzi perspektivy těch, kdo byli Odysseovi podřizeni, tj. mužů, kteř́ se nepodíleli na rozhodování, jakož i žen a bezprávných otroki̊․

V současné epoše globálního kapitalismu ${ }^{8}$ je nutné v regionálním i kosmopolitním rámci věnovat pozornost systémovým a strukturálním problémům i specifickým subjektům. Již bylo zmíněno, že dnešní vlastníci korporací a na ně navázaní politici, manažeři a odborní pracovníci se řídí logikou instrumentální racionality zisku a vytvářejí spotřebitele tím, že především v západních společnostech tlačí lidi do bludného kruhu „nekonečného“ ekonomického růstu a nesmyslné masové spotřeby za cenu značných sociálních a environmentálních škod (Suša - Stahel 2016), a to škod především v rozvojových zemích. Spotřebitelé se tomuto tlaku nebrání, a nesou proto svi̊j díl odpovědnosti za negativní

\footnotetext{
${ }^{7}$ Viz. Atwood (2005); srov. Jaggar (2005).

${ }^{8}$ Viz. Sklair (2016); Robinson (2014); Harris (2016).
} 
důsledky svého vlastního životního stylu, třebaže si toho stále ještě nejsou dostatečně vědomi. Avšak dlouhodobý historický technologický rozvoj, spojený s expanzí instrumentální racionality, není př́mo ani vědomě určován individuálními aktéry, a jednotlivé možnosti korekce založené na individuálním jednání v jedné generaci jsou tudíž velmi omezené (Berdinesen 2018). Korekce proto musí získat podobu dlouhodobé globální intersubjektivní činnosti zahrnující individuální a především kolektivní institucionalizované aktéry. To není pouze morální otázka, ale především otázka civilizační z hlediska dlouhodobějšího a otázka politická, ekonomická, ekologická, sociální a kulturní $\mathrm{z}$ hlediska současného.

\section{Závěr}

Analýzu závažných patologií a nespravedlností naší lidské civilizace lze ve spojitosti s ekologickými návrhy OSN považovat za relevantní kritické memento tváří $\mathrm{v}$ tvář současné globální environmentální krizi, podobné tomu, kterým byla práce o dialektice osvícenství v době druhé světové války. Tomuto príistupu můžeme porozumět jako pozitivnímu alarmismu, jenž může podnítit dosud pasivní subjekty k žádoucí změně. Obvyklý primitivní a myšlenkově bulvární alarmismus pochopitelně není žádným řešením. Zato alarmismus propracovaný a teoretický promyšlený se vzhledem k tomu, že politici, korporace a konzumenti dosud nereagují na současné sociální a environmentální konflikty dostatečně, může stát vhodnou cestou. On sám však může být jen prvním krokem k hlubší a kosmopolitní komplexnější kritické, explanační a normativní analýze, která je založena na dlouhodobých rozborech potřeb a zájmů lidí (Hrubec 2011). Taková analýza založená filosoficky a rozvinutá $\mathrm{v}$ sociálních a prírodních vědách by posléze měla vést $\mathrm{k}$ ustavení adekvátnější praxe intersubjektivních vztahů mezi lidmi navzájem a mezi lidmi a př́rodou, praxe zaměřené na nepatologické, spravedlivé a ekologické udržitelné vývojové tendence směřující od lokální úrovně k úrovni globální. ${ }^{9}$

Skeptikové mohou zajisté namítnout, že pozitivní alarmismus stejně jako informační kampaně z posledních dekád pravděpodobně nebude fungovat. Pokud by tomu tak bylo, museli bychom zvážit scénář nastíněný Georgem Monbiotem, podle něhož je „lidová revolta jedinou cestou, jak bojovat proti klimatickému kolapsu“" (Monbiot 2018). A jestliže by neuspěla ani ona, pak bychom na kolaps nemuseli př́liš dlouho čekat. Zbývala by už jen naděje, že kolaps nebude př́liš velký. Poté by se mohla objevit druhá šance pro pozitivní alarmismus, nebot' by se mohl otevřít prostor „emancipačnímu potenciálu světové katastrofy“ (Beck 2015) ${ }^{10}$, jinými slovy motivační prostor pro pozitivní aspekty negativního vývoje, jak tomu po katastrofách bývá.

\footnotetext{
${ }^{9}$ Srov. Löwy (2015); Williams (2010).

${ }^{10}$ Srov. Suša - Hrubec a kol. (2017).
} 


\section{Literatúra}

ADORNO, T. W. (1941): Veblen's Attack on Culture. Studies in Philosophy and Social Science, IX, $389-413$.

ADORNO, T. W., HORKHEIMER, M. (2007): Dialectic of Enlightenment. Stanford University Press. ARNASON, J. (2009): Civilizační analýza. Evropa a Asie opět na rozcestí. Praha: Filosofia.

ATWOOD, M. (2005): The Penelopiad. New York: Knopf.

BECK, U. (2015): Emancipatory Catastrophism. Current Sociology, 63 (1), 75 - 88.

BENJAMIN, N. (1973): Civilizational Complexes and Intercivilizational Encounters. Sociological Analysis, 34 (2), $79-105$.

BERDINESEN, H. (2018): Future Generations and Concepts of Well-Being. Filozofia, 73 (4), 305 317.

BOSTROM, N. (2011): Global Catastrophic Risks. Oxford: Oxford University Press.

EISENSTADT, S. N. (ed.). (2002): Multiple Modernities. New Brunswick: Transactions Publishers. HABERMAS, J. (2015): The Theory of Communicative Action. Vol. 1. Cambridge: Polity.

HARRIS, J. (2016): Global Capitalism and the Crisis of Democracy. Atlanta: Clarity Press.

HEGEL, G. W. F. (2018): Phenomenology of Spirit. Cambridge: Cambridge University Press.

HOMER. (1999): Oddysey. London: Penguin Classics.

HONNETH, A. (2000): The Possibility of a Disclosing Critique of Society: The Dialectic of Enlightenment in Light of Current Debates in Social Criticism. Constellations, 7 (1), 116 - 127.

HONNETH, A. (2011): Das Recht der Freiheit. Grundriß einer demokratischen Sittlichkeit. Berlin: Suhrkamp.

HORKHEIMER, M. (1941): Preface. Studies in Philosophy and Social Science, IX (3), 365.

HORKHEIMER, M. (1941): The End of Reason. Studies in Philosophy and Social Science, IX, 366 -388 .

HRUBEC, M. (2011): Od zneuznání ke spravedlnosti. Kritická teorie globální společnosti a politiky. Praha: Filosofia.

HRUBEC, M. a kol. (2013): Etika sociálních konfliktů. Axel Honneth a kritická teorie uznání. Praha: Filosofia.

HRUBEC, M. (2016): Conflicts of the Global State. International Critical Thought, 6 (3), 378 - 392. Intergovernmental Panel on Climate Change Press Release. 8 October 2018, 2018/24/PR, Geneva.

JAGGAR, A. M. (2005): "Saving Amina": Global Justice for Women and Intercultural Dialogue. Ethics and International Affairs, 19 (3), 55 - 75.

JAY, M. (1996): The Dialectical Imagination. Berkeley: University of California.

KOSÍK, K. (1963): Dialektika konkrétního. Praha: Academia 1963.

LAMBERTINI, M. (2018): A New Global Deal for Nature and People Urgently Needed. In: Grooten, M. - Almond, R. E. A. (eds).: WWF 2018. Living Planet Report-2018: Aiming Higher. Gland: WWF, 4.

LEVI-STRAUSS, C. (2012): Tristes Tropiques. London: Penguin Classics.

LÖWY, M. (2015): Ecosocialism. Chicago: Haymarket Books.

MARX, K. (1967): Capital. Vol. 1, New York: International Publishers.

MEADOWS, D. H. - MEADOWS, D. L. - RANDERS, J. - BEHRENS, W. W. (1972): The Limits to Growth. Signet.

MONBIOT, G. (2018): As the fracking protesters show, a people's rebellion is the only way to fight climate breakdown. The Guardian, Oct. 18, 2018. Online: https://www.theguardian.com/- 
commentisfree/2018/oct/18/governments-no-longer-trusted-climate-change-citizens-revolt; navštívené 19.10.2018.

PAN, J. (2016): China's Environmental Governing and Ecological Civilization. Berlin: Springer.

ROBINSON, W. (2014): Global Capitalism and the Crisis of Humanity. New York: Cambridge University Press.

SKLAIR, L. (2016): The Transnational Capitalist Class, Social Movements, and Alternatives to Capitalist Globalization. International Critical Thought, 6 (3), 329 - 341.

SUŠA, O., SŤAHEL, R. (2016): Environmentální devastace a sociální destrukce. Praha: Filosofia.

SUŠA, O., HRUBEC, M. a kol. (2017): Riziková společnost a globálni ohrožení. Ke kritické teorii Ulricha Becka. Praha: Sociologické nakladatelství Slon.

SŤAHEL, R. (2018): Environmentalizmus ako politická filozofia pre 21. storočie. Filozofia, 73 (1), $1-13$.

UN (2012): Transforming our world: the 2030 Agenda for Sustainable Development. Online: https://sustainabledevelopment.un.org/post2015/transformingourworld; navštívené, 13. 12. 2015.

UN (2015): The Paris Agreement. Climate Change. Online: https://unfccc.int/process-andmeetings/the-paris-agreement/the-paris-agreement; navštívené 15. 5. 2016.

WILLIAMS, Ch. (2010): Ecology and Socialism. Chicago: Haymarket Books.

YANG, X -, JIANG, Sh. (eds.) (2018): Challenges Towards Ecological Sustainability in China: An Interdisciplinary Perspective. Berlin: Springer.

Článek vychází v rámci výzkumného programu Globálni konflikty a lokální souvislosti Strategie AV21, Akademie věd ČR.

Marek Hrubec

Centrum globálních studií

Filosofický ústav Akademie věd ČR

Jilská 1

11000 Praha 1

Česká republika

e-mail: hrubec@flu.cas.cz 